\title{
DISTRIBUTION OF Hoya multiflora Blume AT GUNUNG GEDE PANGRANGO NATIONAL PARK, INDONESIA
}

\author{
Sri Rahayu ${ }^{1,2}$, Cecep Kusmana ${ }^{3}$, Rochadi Abdulhadi ${ }^{4}$, \\ Muhammad Jusuf 5 and Suharsono ${ }^{5}$
}

\begin{abstract}
Hoya multiflora is one of the valuable germplasm in Indonesia that has been utilized as ornamental and medicinal plant. This epiphytic plant faces problems in decreasing habitat. As a means for developing a habitat framework for describing the distributions and ecological relations of H. multiflora at Gunung Gede Pangrango National Park, Bogor, Indonesia, ecological study of this species was established over the ranges of altitudes and characteristic vegetation structural types (primary and secondary forest, and plantation) present in the Park. Recognizing the fact that such study requires multidisciplinary data, this paper explores the evidences from both herbarium sheets and field observations. The result of the study showed that the population of this species was only found at the Bodogol Research Station at elevation of $700-900 \mathrm{~m}$ above sea level (a.s.l.). Thus, the facts contradict with the evidence from the herbarium sheets of the Herbarium Bogoriense which have presumed that this species has a wide variation of altitudinal range from 20 to $1500 \mathrm{~m}$ a.s.l. (Indonesia) or 200 - $1400 \mathrm{~m}$ a.s.l. (Java). The Bodogol's population showed the clumped type of dispersion (Morisita's Index $=1.35$ ), which indicated such environment that was characterized by patchy resources. Direction and speed of wind coupled with the topography are ecological factors that affect to the distribution of this parachute typed seeds of the H. multiflora.
\end{abstract}

Keywords: Gunung Gede Pangrango National Park, Hoya multiflora, plant ecology, population distribution

\section{INTRODUCTION}

Hoya multiflora Blume (Asclepiadaceae) is one of the ornamental plants with the medicinal properties (Zachos, 1998). This species has been used traditionally to treat arthritis-rheumatism (Burkill, 2002), and stomach/intestinal ailments (Ambasta, 1986). So far, the active compound of this plant has not been identified yet, but presumably it contains indomethacin-like compound. It is a common non-steroidal anti-inflammatory drug (NSAID) that has been used for more than 30 years to treat symptomatic pain of arthritis-rheumatism. Recently, this compound has been tested for a new drug as anti

\footnotetext{
${ }^{1}$ Bogor Botanical Gardens, Jl. Ir. H. Juanda 13 Bogor

${ }^{2}$ Corresponding Author. Email: srirahayukrb@yahoo.com

${ }^{3}$ Department of Silvicultur, Faculty of Forestry, Bogor Agricultural University, Bogor, Indonesia

${ }^{4}$ Laboratory of Ecological Science, Research Centre for Biology, Indonesian Institute of Science (LIPI), Cibinong Science Centre, Bogor, Indonesia

${ }^{5}$ Department Biology, Faculty of Mathematic and Natural Sciences, Bogor Agricultural University,

Bogor, Indonesia
} 
HIV (Bourinbaiar and Lee-Huang, 1995), and it seems to be specific since no toxicity has been observed at the $\mathrm{IC}_{50}$ dose, and unrelated NSAIDs have not shown the activity at clinical doses.

Hoya multiflora is widely distributed throughout India to New Guinea (Schlechter, 1914; Thaitong, 1994), at the elevation of 200 - $1200 \mathrm{~m}$ a.s.l. (Backer and van der Brink, 1965; Rintz, 1980). This species is characterized by its short (non vein) plant, leathery (non succulent) oblong leaves, white coronas flowers and yellow/white reflexed corollas (Wanntorp et al., 2006). There can be up to 40 of these rockets like flowers in an umbel and they produce lots of nectar and white latex from all of its part (Goyder, 2008). In Indonesia, as an ornamental plant, this species is highly demanded and commonly sold as cuttings, either rooted or unrooted at IDR 15000 - 30000 (equivalent to USD 1.60) per stick for seedling, and IDR 75000 - 100000 (equivalent to USD 9.50) per pot (Rahayu, 2006). Unfortunately, most of the traded plants have been harvested directly from the wild.

Despite of their high economic importance, little is known about their population ecology, particularly the ecological factors that affect its distribution. Thus, it is imperative to study the population ecology of $H$. multiflora, including those which are present at the Gunung Gede Pangrango National Park (GGPNP), West Java, Indonesia.

The objectives of this study was to evaluate the ecological factors that affect the distribution of $H$. multiflora in GGPNP, West Java. It is expected that the result of the study will provide complete information on the status of such species in this National Park.

\section{METHODS}

The process of data collection was conducted by observing herbarium sheets, field observations, and plot sampling. Herbarium observation was conducted on the all of herbarium sheets collection of $H$. multiflora from Indonesia's Islands in the Herbarium Bogoriense. A total of 70 sheets was observed. The information recorded was the collector's notes, i.e. collection date, location, altitude, longitude (if any), topography and habitat.

Field observation was implemented in two steps: (1) Inventory to the occurrence of $H$. multiflora at the GGPNP by different elevation, and (2) the distribution of populations at the habitat (at the sites where $H$. multiflora found). Inventory was done by belt transects observation (Cox, 2002) vertically from below to the top of mountain at different elevation, from 700 to $1500 \mathrm{~m}$ a.s.l. The sampling was done at four different sites (research stations) as follows: (i). Cibodas (at the elevation of $1450 \mathrm{~m}$ a.s.l,); (ii) Bodogol (at the elevation of $760 \mathrm{~m}$ a.s.l.); (iii) Situ Gunung (at the elevation of $1000 \mathrm{~m}$ a.s.l.); and (iv) Cugenang/Gedeh (at the elevation of $900-1500 \mathrm{~m}$ a.s.l). The observations were done at the sample plots of $20 \mathrm{~m}$ x $20 \mathrm{~m}$ at every $100 \mathrm{~m}$ of elevation. 
The population distribution was observed at the site where $H$. multiflora found (i.e. Bodogol). The field observations were conducted at the four selected hilly areas with different sides/directions. Two of those four hills were facing east and west directions, whereas the other two hills were selected facing north and south sides/directions, and physiographical condition of those hills are characterized by different forest and vegetation types. The elevation coverage is between 650 (lowest valley) and $900 \mathrm{~m}$ a.s.l. (highest hill), that lies between latitudes 6 $6^{\circ} 5^{\prime} 51.2^{\prime \prime} \mathrm{S}-6^{\circ} 46^{\prime} 57.0^{\prime \prime} \mathrm{S}$ and longitudes $106^{\circ} 50^{\prime} 29.6^{\prime \prime} \mathrm{E}-106^{\circ} 51^{\prime} 38.7^{\prime \prime} \mathrm{E}$. The pattern of distribution was measured using Morisita Index of dispersion (Krebs, 1989) as follows:

$$
I d=n \cdot \frac{\left(\sum x^{2}-\sum x\right)}{\left(\sum x\right)^{2}-\sum x}
$$

where:

Id $=$ Morisita's Index of dispersion

$\mathrm{n}=$ Number of observation

$\mathrm{x}=$ Number of individual plants

The pattern of distribution was defined by Chi-square test as follows:

$$
\begin{aligned}
& M u=\frac{\chi_{0.975}^{2}-n+\sum x_{i} \text { for uniform pattern, }}{\left(\sum x_{i}\right)-1} \\
& M c=\frac{\chi_{0.025}^{2}-n+\sum x_{i}}{\left(\sum x_{i}\right)-1} \text { for clumping pattern }
\end{aligned}
$$

where:

$\mathrm{Mu}=$ Morisita's Index of dispersion for uniform pattern

$\mathrm{Mc}=$ Morisita's Index of dispersion for agregatif (clumped) pattern

$\chi_{0.975}^{2}=$ Chi-square at $\mathrm{db}(\mathrm{n}-1), 97.5 \%$.

$\sum x_{i}=$ Number of individual plants at sample unit $-\mathrm{i}$

$\mathrm{n} \quad=$ Number of sample units

Morisita's Index (Ip) was measured by four formulas as follows:

1. If $\mathrm{Id}^{3} \mathrm{Mc}>1.0$, then:

$$
I p=0.5+0.5\left(\frac{I d-M c}{n-M c}\right)
$$

2. If $\mathrm{Mc}>\mathrm{Id}^{3} 1.0$, then:

$$
I p=0.5\left(\frac{I d-1}{M c-1}\right)
$$


3. If $1.0>\mathrm{Id}>\mathrm{Mu}$, then:

$$
I p=-0.5\left(\frac{I d-1}{M u-1}\right)
$$

4. If $1.0>\mathrm{Mu}>\mathrm{Id}$,then:

$$
I p=-0.5+0.5\left(\frac{I d-M u}{M u}\right)
$$

The pattern was defined by the Ip number as follows:

$I p=0$, random pattern

Ip $<0$, uniform pattern and

Ip $>0$, clumped pattern

\section{RESULTS AND DISCUSSION}

\section{A. Results}

\section{Herbarium Observations}

The herbarium observation was done at the 70 sheets which have indicated that $H$. multiflora is widely distributed. This species was found throughout Sumatra to Maluku, and has broad physiographic division - lowlands, midlands and highlands. The lowland starts at the elevation of $20 \mathrm{~m}$ to the high mountain at the elevation of $1500 \mathrm{~m}$ (Table 1 ).

Table 1. The distribution of $H$. multiflora in Indonesia based on the observation of

\begin{tabular}{|c|c|c|c|c|c|}
\hline Island & $\begin{array}{c}\text { No of } \\
\text { sheets } \\
\text { observed } \\
(n=70)\end{array}$ & $\begin{array}{l}\text { Elevation } \\
\text { (m a.s.l.) }\end{array}$ & $\begin{array}{l}\text { Year of sheets } \\
\text { produced }\end{array}$ & Habitats & Topography \\
\hline Sumatra & 10 & $20-1500$ & $1916-1983$ & $\begin{array}{l}\text { Secondary forest/ } \\
\text { durian plantation }\end{array}$ & Hill forest \\
\hline Java & 38 & $200-1400$ & $1896-1978$ & Secondary forest & Hill \\
\hline Kalimantan & 7 & $20-600$ & $1925-1977$ & Dry forest, rivulet & - \\
\hline Sulawesi & 9 & $300-1000$ & $1893-2002$ & Forest & Gentle slope \\
\hline $\begin{array}{l}\text { Nusa } \\
\text { Tenggara }\end{array}$ & 5 & $50-600$ & $1927-1961$ & $\begin{array}{l}\text { Rock near river, } \\
\text { deciduous forest }\end{array}$ & - \\
\hline Maluku & 1 & 50 & 1921 & $\begin{array}{c}\text { Buru Island, no info } \\
\text { habitat type }\end{array}$ & - \\
\hline
\end{tabular}
herbarium sheets of Herbarium Bogoriense, Bogor, Indonesia 
Results in Table 1 indicate that the species tolerates a wide range of habitat and has high adaptability to the ecological diversities of the region. However, there is no evidence of $H$. multiflora herbarium sheet from GGPNP. The species was not listed in "Flora Taman Nasional Gede Pangrango" of Sunaryo and Rugayah (1992). The elevation range at GGPNP was formerly from 900 to 3,019 m a.s.l. After 2003, the area was extended to the lower elevation, from 650 m a.s.l at Bodogol (Balai Taman Nasional Gunung Gede Pangrango official, personal communication). Based on the herbarium sheet observations, particularly the 38 herbarium sheets of Java, most of $H$. multiflora $(68 \%)$ are present at the elevation of $500-1,000 \mathrm{~m}$ a.s.l. (Table 2).

Table 2. Number of $H$. multiflora Blume herbarium sheets according to level of elevation

\begin{tabular}{|c|c|c|c|c|c|c|c|c|c|c|c|c|c|c|c|}
\hline \multirow[t]{2}{*}{ No } & \multirow{2}{*}{$\begin{array}{c}\text { Elevation } \\
\text { (m a.s.l.) }\end{array}$} & \multicolumn{2}{|c|}{ Sumatra } & \multicolumn{2}{|c|}{ Java } & \multicolumn{2}{|c|}{ Kalimantan } & \multicolumn{2}{|c|}{ Sulawesi } & \multicolumn{2}{|c|}{$\begin{array}{c}\text { Nusa } \\
\text { Tenggara }\end{array}$} & \multicolumn{2}{|c|}{ Maluku } & \multicolumn{2}{|c|}{ Total } \\
\hline & & $\mathrm{n}$ & $\%$ & $\mathrm{n}$ & $\%$ & $\mathrm{n}$ & $\%$ & $\mathrm{n}$ & $\%$ & $\mathrm{n}$ & $\%$ & $\mathrm{n}$ & $\%$ & $\mathrm{n}$ & $\%$ \\
\hline 1 & $0-250$ & 4 & 40 & 3 & 8 & 5 & 71 & - & - & 1 & 20 & 1 & 100 & 14 & 20,0 \\
\hline 2 & $250-500$ & 3 & 30 & 7 & 18 & - & - & 4 & 44 & 3 & 60 & - & - & 17 & 24,3 \\
\hline 3 & $500-75$ & 1 & 10 & 11 & 29 & 2 & 29 & - & - & 1 & 20 & - & - & 15 & 1,4 \\
\hline 4 & $750-1000$ & 1 & 10 & 15 & 39 & - & - & 5 & 56 & - & - & - & - & 21 & 30,0 \\
\hline \multirow[t]{2}{*}{5} & $>1000$ & 1 & 10 & 2 & 5 & - & - & - & - & - & - & - & - & 3 & 4,3 \\
\hline & Total & \multicolumn{2}{|c|}{10} & \multicolumn{2}{|c|}{38} & \multicolumn{2}{|c|}{7} & & & & \multicolumn{2}{|c|}{70} \\
\hline
\end{tabular}

\section{The Occurrence of $\boldsymbol{H}$. multiflora}

Based on the field observations, the results showed surprising evidences that H. multiflora were not present at the three sites of the park, i.e. Cibodas $(1400 \mathrm{~m})$, Situgunung (1000 m), and Cugenang/Gedeh (950 m). It was only found at the Bodogol Research Station at the elevation of 700 - $900 \mathrm{~m}$ a.s.l. (Table 3). Thus, this fact contradicts with the evidence from the herbarium sheets of the Herbarium Bogoriense which have presumed that this species has a physiographic division of an altitudinal range from 20 to $1500 \mathrm{~m}$ a.s.l. (Indonesia) or 200 - $1400 \mathrm{~m}$ a.s.l. (Java). Although there is no herbarium sheet of $H$. multiflora from GGPNP, it was presumably there was $H$. multiflora at any location at GGPNP under the elevation of $1500 \mathrm{~m}$ a.s.l. 
Table 3. The occurrence of H. multiflora Blume at GGNP

\begin{tabular}{lccccc}
\hline \multicolumn{1}{c}{ Track/Station } & $\begin{array}{c}\mathrm{RH}^{*} \\
(\%)\end{array}$ & $\begin{array}{c}\mathrm{AT}^{*} \\
\left({ }^{\circ} \mathrm{C}\right)\end{array}$ & $\begin{array}{c}\mathrm{RF}^{*}(\mathrm{~mm} / \\
\text { year})\end{array}$ & $\begin{array}{c}700-1000 \mathrm{~m} \\
\text { a.s.l. }\end{array}$ & $1000-1500 \mathrm{~m}$ a.s.l. \\
\hline $\begin{array}{l}\text { Cibodas } / 1450 \text { m a.s.l. } \\
\text { (Pacet) }\end{array}$ & 81.75 & 20.81 & 3113.7 & Not observed & Not present \\
$\begin{array}{l}\text { Bodogol } / 650 \mathrm{~m} \text { a.s.l. } \\
\text { (Citeko) }\end{array}$ & 83.08 & 21.03 & 3190.3 & $\begin{array}{c}\text { Present at } \\
750-900 \mathrm{~m}\end{array}$ & Not present \\
$\begin{array}{l}\text { Situgunung/950 m a.s.l. } \\
\text { (Goalpara) }\end{array}$ & 84.67 & 20.83 & 3250.2 & Not present & Not present \\
$\begin{array}{l}\text { Gedeh/ } 950 \text { m a.s.l. } \\
\text { (PSarongge) }\end{array}$ & 82.36 & 20.32 & 188.0 & Not present & Not present \\
\hline * source: BMKG station (2008): $\mathrm{RH}=$ relative humidity; $\mathrm{AT}=$ average temperature; $\mathrm{RF}=$ rainfall
\end{tabular}

\section{Distribution and Habitat of $\boldsymbol{H}$. multiflora at Bodogol Research Station}

As reported by the Indonesian Agency for Meteorology, Climatology and Geophysics (BMKG) of Citeko BMKG station, in the last 5 years (2004-2008) the average annual rainfall was $3041.36 \mathrm{mn}$ year $^{-1}(3190.3 \mathrm{~mm}$ in 2008$)$; the relative humidity was $83.21 \%$ (83.08\% in 2008) and the temperature was $21.09^{\circ} \mathrm{C}\left(21.03^{\circ} \mathrm{C}\right.$ in 2008). Table 4 shows that the population of $\mathrm{H}$. multiflora is only found at east-west faced hill (Figure 1) at the elevation of 765 - $872 \mathrm{~m}$ a.s.l.; and lies between $106^{\circ} 50^{\prime} 45.7^{\prime \prime} \mathrm{E}-106^{\circ} 51^{\prime} 36.4^{\prime \prime} \mathrm{E}$, and between $6^{\circ} 46^{\prime} 32.3^{\prime \prime} \mathrm{S}-6^{\circ} 46^{\prime} 39.8^{\prime \prime} \mathrm{S}$.

The population distribution of $H$. multiflora at the Bodogol does not concordance by forest type or vegetation type presence as expected before. Similar condition at the other hills does not result with the same preference of $H$. multiflora (Table 4). 
Table 4. Population occurrence of H. multiflora Blume at Bodogol Research Station

\begin{tabular}{|c|c|c|c|c|c|c|c|}
\hline \multirow[b]{2}{*}{ Plot } & \multirow{2}{*}{$\begin{array}{c}\text { Hill } \\
\text { Aspect }\end{array}$} & \multirow{2}{*}{$\begin{array}{l}\text { Slope } \\
\text { Aspect }\end{array}$} & \multirow{2}{*}{$\begin{array}{c}\text { Forest } \\
\text { Type }\end{array}$} & \multicolumn{3}{|c|}{ Vegetation } & \multirow{2}{*}{$\begin{array}{c}\text { Density } \\
\text { of } H . \\
\text { multiflora }\end{array}$} \\
\hline & & & & $\begin{array}{c}\text { Dominant } \\
\text { tree }\end{array}$ & $\begin{array}{l}\text { Dominant } \\
\text { pole }\end{array}$ & $\begin{array}{l}\text { Dominant } \\
\text { understory }\end{array}$ & \\
\hline 1 & $\begin{array}{l}\text { East west } \\
\text { la }\end{array}$ & North & SF & $\begin{array}{l}\text { Maesopsis } \\
\text { eminii }\end{array}$ & $\begin{array}{l}\text { Cyathea } \\
\text { contaminans }\end{array}$ & $\begin{array}{l}\text { Sellaginella } \\
\text { sp. }\end{array}$ & $42 / \mathrm{Ha}$ \\
\hline 2 & $\begin{array}{l}\text { East west } \\
\text { 1a }\end{array}$ & South & PF & $\begin{array}{l}\text { Nauclea } \\
\text { lanceolata }\end{array}$ & Pinanga sp. & Donax sp. & $11 / \mathrm{Ha}$ \\
\hline 3 & $\begin{array}{l}\text { East west } \\
1 \mathrm{~b}\end{array}$ & North & SF & $\begin{array}{l}\text { Altingia } \\
\text { excelsa }\end{array}$ & $\begin{array}{l}\text { Pandanus } \\
\text { furcatus }\end{array}$ & $\begin{array}{l}\text { Musa } \\
\text { acuminata }\end{array}$ & $11 / \mathrm{Ha}$ \\
\hline 4 & $\begin{array}{l}\text { East west } \\
1 \mathrm{~b}\end{array}$ & South & SF & $\begin{array}{l}\text { Agathis } \\
\text { damara }\end{array}$ & $\begin{array}{l}\text { Cyathea } \\
\text { contaminans }\end{array}$ & $\begin{array}{l}\text { Sellaginella } \\
\text { sp. }\end{array}$ & 0 \\
\hline 5 & East west 2 & North & $\mathrm{PF}$ & $\begin{array}{l}\text { Schima } \\
\text { wallichii }\end{array}$ & Pinanga sp. & Pinanga sp. & 0 \\
\hline 6 & East west 2 & South & $\mathrm{PF}$ & Quercus sp. & Pinanga sp. & Calamus sp. & 0 \\
\hline 7 & $\begin{array}{l}\text { North } \\
\text { south } 1\end{array}$ & East & SF & $\begin{array}{l}\text { Pinus } \\
\text { merkusii }\end{array}$ & $\begin{array}{l}\text { Calliandra } \\
\text { sp. }\end{array}$ & $\begin{array}{l}\text { Selaginella } \\
\text { sp. }\end{array}$ & 0 \\
\hline 8 & $\begin{array}{l}\text { North } \\
\text { south } 1\end{array}$ & West & SF & $\begin{array}{l}\text { Pinus } \\
\text { merkusii }\end{array}$ & $\begin{array}{l}\text { Calliandra } \\
\text { sp. }\end{array}$ & $\begin{array}{l}\text { Selaginella } \\
\text { sp. }\end{array}$ & 0 \\
\hline 9 & $\begin{array}{l}\text { North } \\
\text { south } 2\end{array}$ & East & SF & - & - & Alpinia sp. & 0 \\
\hline 10 & $\begin{array}{l}\text { North } \\
\text { south } 2\end{array}$ & West & SF & $\begin{array}{l}\text { Sehima } \\
\text { wallichii }\end{array}$ & - & $\begin{array}{l}\text { Chromolaena } \\
\text { odorata }\end{array}$ & 0 \\
\hline
\end{tabular}

Forest Type: $\mathrm{PF}=$ Primary Forest; $\mathrm{SF}=$ Secondary Forest (Formerly planted by PT Perhutani)

It was also noted that the $H$. multiflora only found at the upper areas of the hill and slope, not in the valley area. The seed dispersal strategy by wind and the intensity of sun light are reasons for the site selection.

The type of dispersion is clumped with the Morisita's Index of dispersion=1.35; $\chi 2=22.4$ ( $95 \%$ valid) (see Figure1). Clumped distribution is the most common type of dispersion found in nature. In clumped distribution, the distance between neighboring individuals is minimized. This type of distribution is found in environment that is characterized by patchy resources. 


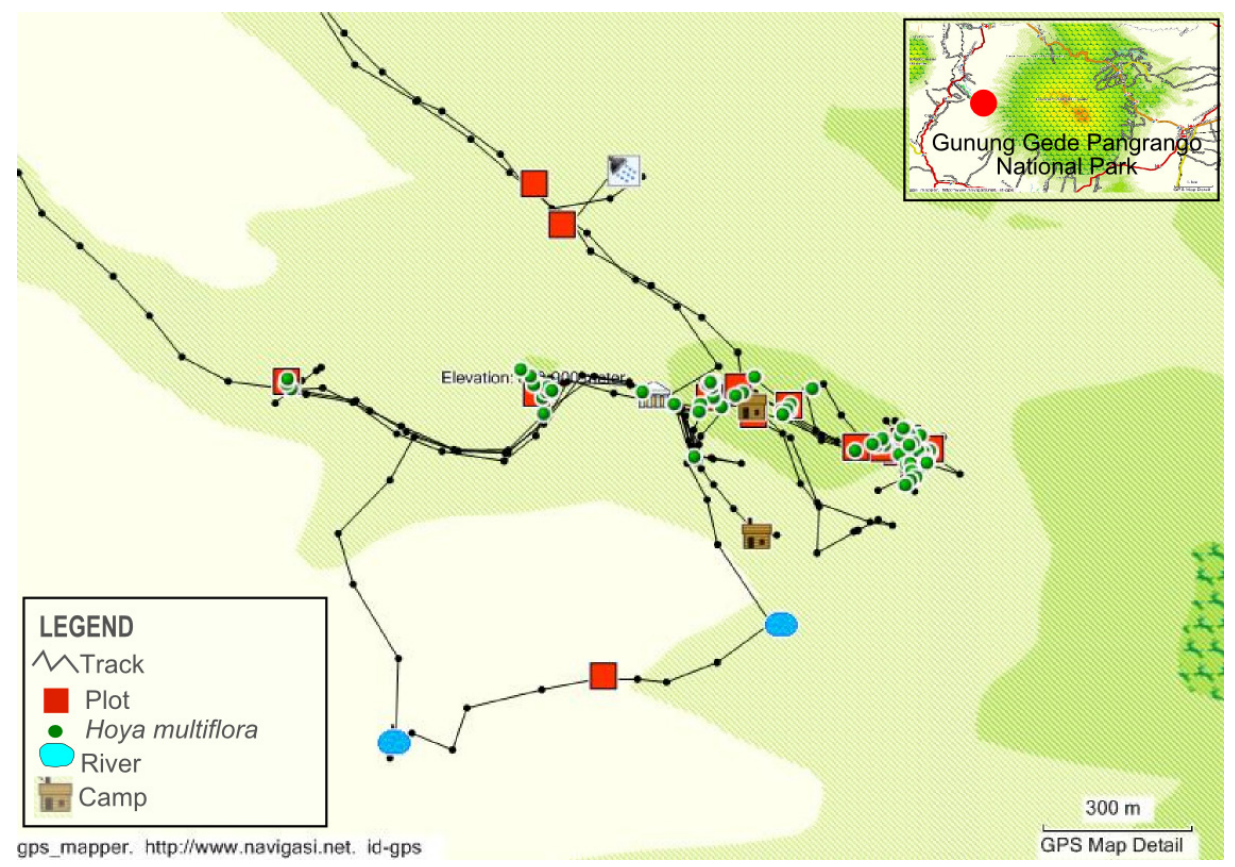

Figure 1. The distribution of $H$. multiflora Blume population at Bodogol Research Station, Gunung Gede Pangrango National Park, Bogor, Indonesia

\section{B. DISCUSSION}

According to the type of distribution, a species can be categorized as cosmopolitan or endemic species. As $H$. multiflora has a wide range of geographic distribution, thus, this species is classified as cosmopolitan species. However, based on the field observations at Gunung Gede Pangrango National Park, H. multiflora was only present at the Bodogol at the elevation of $750-900 \mathrm{~m}$. The three other locations lay at higher elevation above $900 \mathrm{~m}$ a.s.l. As the result from the herbarium observation from Java, most of the sheets (68\%) were found in elevation between 500 - $1000 \mathrm{~m}$ a.s.l.

The physiographic distribution of organisms will continually be shifted, expanded, and contracted depending on situation with the passage of time (Begon et al., 2006). These changes are the result of two contrasting processes: establishment and extinction (Cuddington and Beisner, 2003). According to Krebs (2001), factors that limit distributions are biological dispersal, habitat selection, interrelations with other species and temperature, moisture and other physical-chemical factors. The habitat condition including physical-chemical factors at all locations of GGPNP is quite similar to the other mountains in West Java, where H. multiflora is found up to the elevation of 1400 $\mathrm{m}$ a.s.l (herbarium observation). 
The dispersal seems to be the key factor to the distribution of $H$. multiflora at GGPNP. Biological dispersal refers to a species movement away from an existing population. Through simply moving from one habitat patch to another, the dispersal of an individual has consequences not only for individual fitness, but also for population dynamics, population genetics, and species distribution (Clobert et al., 2004). Understanding dispersal and the consequences on an ecosystem level requires understanding on the type of dispersal and the dispersal mechanisms involved.

Biologically, $H$. multiflora has follicle type fruits and tiny seeds bearing lots of silky hairs. This characteristic allows the seeds to travel the wind current and gentle breezes of the earth. Wind dispersal of seeds, or anemochory, is one of the more primitive means of dispersal. Wind dispersal can take on one of two primary forms: seeds can float on the breeze or alternatively, they can flutter to the ground (Irwini and Taylor, 2007). In the case of this species, it has plumose crown of hairs (pappus) above a slender seed. This type of dispersal adopted this typical characteristic of a parachute seed so this plant evolved parachute method of seed dispersal by wind (Armstrong, 1999).

The H. multiflora dispersal at the Bodogol Research Station can be said primarily depends on the wind speed and direction at the time of fruit opening. Measurement by using (portable) anemometer at the observation time resulted in the southerly wind with the low speed (1-3 knot/hour). According to the data from the Indonesian Agency for Meteorology, Climatology and Geophysics (BMKG) 2008 (personal communication), wind direction above GGPNP (3000 feet) is southwesterly (January-March), southerly (April - May and November - December) and southeasterly (June-October). In areas where there is rugged topography that significantly interrupts the environmental wind flow, the wind circulation between mountains and valleys is the most important contributor to the prevailing winds. Hills and valleys substantially distort the airflow by increasing friction between the atmosphere and landmass by acting as a physical block to the flow, deflecting the wind parallel to the range just upstream of the topography, which is known as a barrier jet. This barrier jet can increase the low level wind by 45 percent (Doyle, 1979). Wind direction also changes due to the contour of the land (ANCAR, 2006).

\section{CONCLUSION}

H. multiflora has widespread geographic distribution found in almost all parts of Indonesian archipelago ranging from 20 to $1500 \mathrm{~m}$ above sea level. The distribution of $H$. multiflora at the Gunung Gede Pangrango National Park is between $650-900 \mathrm{~m}$ above sea level at the Bodogol Research Station. The main factor affecting the spatial distribution is seed dispersal which mainly depends on the wind as a primary dispersal agent, rather than habitat factors. The speed and direction of the wind also influence on the long and short distant dispersal of this species. 


\section{REFERENCES}

Ambasta, S.P. 1986. The Useful Plants of India. Publication and Information Directorate, Council of Scientific and Industrial Research, New Delhi. 918p.

[ANCAR] American National Center for Atmospheric Research. 2006. T-REX: Catching the Sierra's waves and rotors. University Corporation for Atmospheric Research. Accessed from: http://www.ucar.edu/communications/quarterly/ spring06/trex.jsp. on 2 September 2009.

Armstrong, W.P. 1999. "Blowing in the wind: seed \& fruit dispersal by wind." Wayne's Word Noteworthy Plants. Accessed from http://waynesword.palomar.edu/ plfeb99.htm on 12 September 2009.

Backer, C.A. and R.C. Bakhuizen van der Brink, Jr. 1965. Flora of Java. Vol II. Groningen, Noordhoff. 641p.

Begon, M., C.R. Townsend, and J.L. Harper. 2006. Ecology: From Individuals to Ecosystems ( $4^{\text {th }}$ ed.). Blackwell, Singapore. 714p.

Bourinbaiar, A.S. and S. Lee-Huang. 1995. The non-steroidal anti-inflammatory drug, Indomethacin, as an inhibitor of HIV replication. FEBS Letters 360 (1): 85-88.

Burkill, I.H. 2002. Dictionary of Economic Product of Malay Peninsula. Vol. 2. Ministry of Agriculture Malaysia, Kuala Lumpur, Malaysia. 2444p.

Clobert, J., R.A. Ims, and F. Rousset. 2004. Causes, mechanisms and consequences of dispersal. In: Hanski, I. and O.E. Gaggiotti (Eds.). Ecology, Genetics and Evolution of Metapopulations. Academic Press, San Diego. Pp. 307-335.

Cox, G.W. 2002. General Ecology Laboratory Manual. Mc Graw Hill, New York. 312p.

Cuddington, K. and B. Beisner. 2003. Ecological Paradigms Lost. Routes of Theory Change. Elsevier, Amsterdam. 435p.

Doyle, J.D. 1997. The influence of mesoscale orography on a coastal jet and rainband. Monthly Weather Review 125 (7): 1465-1488. Accessed from http://cat.inist.fr/? aModele $=$ afficheN\&cpsidt $=2721180$. on 25 December 2008 .

Goyder, D. 2008. Hoya multiflora Blume (Asclepiadaceae). Curti’s Bot. Magazine 7 (1): 3-6.

Irwini, A.J. and P.D. Taylor. 2007. Evolution of dispersal in a stepping-stone population with overlapping generations. Theoretical Population Biology 58:321-328.

Krebs, C.J. 1989. Ecological Methodology. Benjamin Cummings, Menlo Park, CA. $620 \mathrm{p}$.

Krebs, C.J. 2001. Ecology. The Experimental Analysis of Distribution and Abundance ( $5^{\text {th }}$ ed.). Benjamin Cumming, San Francisco. 695p. 
Rahayu, S. 2006. Hoya multiflora Blume. In: Sutarno H., D. Darnaedi and Rugayah (Eds.) Tanaman Hias dalam Ruangan di Indonesia. P2B - LIPI, Bogor. Pp. 80-82.

Rintz, R.E. 1980. The biology and cultivation of Hoyas. Asclepiadaceae 19:9-17.

Schlechter, F.R.R. 1914. Die Asclepiadaceen von Deutch Neu Guinea. Botaniche Jabrbücher für Systematik 50: 104-138.

Sunaryo and Rugayah. 1992. Flora Taman Nasional Gede Pangrango. Herbarium Bogoriense, Bogor. 219 p.

Thaitong, O. 1994. The genus Hoya in Thailand. Proceedings of Botany 2000 ASIA Intern. Seminar and Workshop. Melacca, June 1994. Pp.83-94.

Wanntorp, L., A. Koycan, and S. Renner. 2006. Wax plants disentangled: A phylogeny of Hoya (Marsdenieae, Apocynaceae) inferred from nuclear and chloroplast DNA sequences. Molecular Phylogenetics and Evolution 39: 722-733.

Zachos, E. 1998. Practical uses of various Hoya species. The Hoyan 19 (4) / 20 (1): 6-10/3-8. 